\title{
Plant communities of the Ebenhaezer section of the Mountain Zebra National Park
}

\author{
J. DE KLERK, L.R. BROWN and H. BEZUIDENHOUT
}

De Klerk, J., L.R. Brown and H. Bezuidenhout. 2003. Plant communities of the Ebenhaezer section of the Mountain Zebra National Park. Koedoe 46(2): 9-20. Pretoria. ISSN 0075-6458.

\begin{abstract}
The long-term conservation of viable ecosystems requires a broader understanding of the ecological processes involved. Because ecosystems react differently to different management practices, it is important to have a description and classification of the vegetation of an area available. As part of a vegetation survey programme for the newly acquired farms to be incorporated into the Mountain Zebra National Park, the vegetation of the Ebenhaezer section was investigated. A hierarchical classification, vegetation map, description and ecological interpretation of the plant communities of the study area are presented. A TWINSPAN classification, refined by Braun-Blanquet procedures revealed eight distinct plant communities. Habitat factors associated with differences in vegetation include topography, soil form and grazing. Descriptions of the plant communities include diagnostic species as well as prominent and less conspicuous species of the tree, shrub and herbaceous layers.
\end{abstract}

Key words: Braun-Blanquet procedures, conservation area, plant communities, TWINSPAN, vegetation classification.

J. de Klerk and L.R. Brown, Applied Natural Sciences, Technikon SA, Private Bag X6, Florida, 1710 Republic of South Africa; H. Bezuidenhout, Conservation Services, South African National Parks, P.O. Box 110040, Hadison Park, Kimberley, 8306 Republic of South Africa.

\section{Introduction}

The Mountain Zebra National Park (MZNP), situated in the Eastern Cape Province of South Africa, was proclaimed in 1937 (Wahl \& Naude 1996) to preserve the last mountain zebra (Equus zebra zebra L., 1758) population in the Bankberg area of the park. The first proclaimed section was only 1712 ha in size and too small to carry a viable mountain zebra population. In order to accommodate a more viable mountain zebra population, it was decided during the 1960s to enlarge the park. Neighbouring farms were purchased and the park was enlarged to 6536 ha. A detailed phytosociological study on the vegetation of the enlarged park was conducted by Van der Walt in 1980.

In the early $1990 \mathrm{~s}$, a further long-term project to enlarge the park was initiated. From 1996, various farms adjacent to the MZNP were acquired and incorporated into the park. One of the farms, Ebenhaezer, also known as Wendover, became part of the greater Mountain Zebra National Park during the 1999/2000 period.

Vegetation classification and mapping forms an integral part of ecological planning in a conservation area (Edwards 1972). According to Harper \& Hawksworth (1995) biological inventories are needed if full quantitative measures of biodiversity are to be used in making conservation decisions. Certain parts of MZNP have already been studied in this respect. Brown \& Bezuidenhout (2000) have described fourteen plant communities in the De Rust area. A study by Pond et al. (2002) indicated that the species richness (680 plant species) in MZNP is considerably higher when compared to other parks and reserves in the more arid regions of South Africa. 


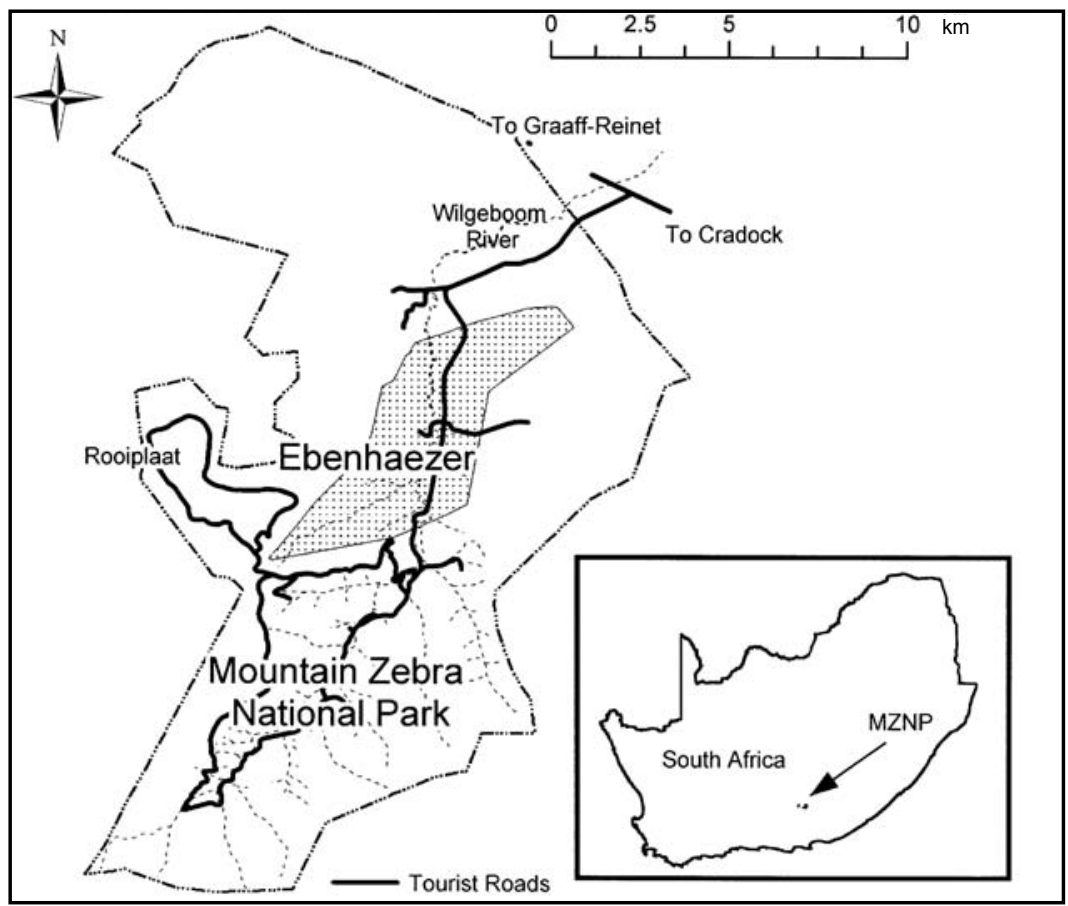

Fig. 1. Location of the study area in Mountain Zebra National Park (Compiled by S. Holness).

Descriptions of the plant communities (inventories) on the new farms incorporated into MZNP are therefore necessary

\section{Study Area}

The Ebenhaezer section of Mountain Zebra National Park is situated approximately $18 \mathrm{~km}$ west of the town of Cradock in the Eastern Cape (Fig. 1). The study area comprises 1800 ha and lies directly north of the previously proclaimed section of MZNP, where it borders onto the Rooiplaat plateau. It extends from latitude $32^{\circ} 09^{\prime}-32^{\circ} 14^{\prime} \mathrm{S}$ and longitude $25^{\circ} 25^{\prime}-25^{\circ} 31^{\prime} \mathrm{E}$. Hoffman (1996) classified this section as Eastern Mixed Nama Karoo (52), while Acocks (1988) classified the area as False Karroid Broken Veld (37). The Wilgerboom River acts as the main functional drainage system, that extends from the old park into the study area. The eastern and western areas are mountainous and consist of moderate to steep slopes. The vegetation comprises mainly of a complex mixture of grass-and-shrub-dominated vegetation types (Hoffman 1996). The central area comprises lower lying drainage lines characterised by mixed Acacia karroo veld, as well as disturbed fields, previously used for cultivation purposes. However, this cultivated field covers less than $1 \%$ of the total study area.

\section{Land types}

Three land types, namely $\mathrm{Fc}, \mathrm{Ib}$ and $\mathrm{Da}$ are prominent in the study area. A remarkable association between the major plant communities and the different land types have been observed. The land type concept has frequently provided a useful basis for descrip- 
tion of vegetation (Bezuidenhout 1993; Eckhardt 1993; Götze 2002).

The geology in the $\mathrm{Fc}$ land type consists of mudstone, shale and sandstone of the Beaufort Group of the Karoo Sequence with rare dolerite intrusions. The main topographical positions present in this land type are footslopes, midslopes and valley bottoms. Glenrosa and Oakleaf soil forms are characteristic of this land type. Underlying limestone is present in the valley bottoms (Land Type Survey Staff 1999).

The Ib land type can be associated with midslopes in mountainous areas. The rock cover in this land type is approximately 50-60\% and consists of exposed sandstone rocks. The geology depicts dolerite with mudstone, shale and sandstone of the Beaufort Group of the Karoo Sequence (Land Type Survey Staff 1986). The Mispah soil form is prominent in this land type (Land Type Survey Staff 1999).

The upper plateau area in the south western section of the study area includes the Da land type with a rock cover of less than $50 \%$, with mudstone, shale and sandstone of the Balfour Formation in the Beaufort Group of the Karoo Sequence as the underlying geology (Land Type Survey Staff 1999).

\section{Climate}

The study area is located within the summer rainfall area of South Africa, with an average rainfall of $389 \mathrm{~mm}$ per annum. The highest annual rainfall recorded was $651 \mathrm{~mm}$ in 1977, while the lowest rainfall recorded was $153 \mathrm{~mm}$, in 1966. The average monthly rainfall varies between $11 \mathrm{~mm}$ in the winter to $61 \mathrm{~mm}$ in summer. During summer (September-March) the average maximum temperatures vary between $23-28^{\circ} \mathrm{C}$, while in the winter (April-August), the average minimum varies between $0-8{ }^{\circ} \mathrm{C}$ (Brown \& Bezuidenhout 2000).

\section{Methods}

The method applied in this study was based on the method described and applied by Brown \& Bezuidenhout (2000) in the De Rust Section of the MZNP. To incorporate this study with similar studies in MZNP it is crucial that the same procedure is followed. The study area was stratified into physiognomic-physiographic units by using 1:50 000 stereo aerial photographs. Relevés were compiled at 47 stratified random plots. Plot sizes were fixed at $400 \mathrm{~m}^{2}$ (Brown 1997). All plant species were recorded in each sample plot and a cover-abundance score was allocated to each species using the Braun-Blanquet cover-abundance scale (Mueller-Dombois \& Ellenberg 1974). An estimation of the percentage canopy cover and average height of the herbaceous, shrub, and tree layer in each sample plot was also noted. Shrubs are defined as woody species varying in height between $>0-3 \mathrm{~m}$ and trees as woody species taller than 3 m (Brown 1997; Brown \& Bezuidenhout 2000).

Topographical characteristics such as aspect, slope, rockiness and soil surface were also noted. The BBPC suite (Bezuidenhout et al. 1996) was used to analyse the floristic data. By applying a Two-way indicator species analysis (TwINSPAN) (Hill 1979) to the floristic data, a first approximation of the main plant communities was derived. Refinement of the classification was achieved by applying Braun-Blanquet procedures. Soil nomenclature follows the classification of the Soil Classification Working Group (1991). Although certain taxon names have changed, the taxon names of this publication conform to those of Arnold \& De Wet (1993). Structural terminology is according to Edwards (1983). No attempt was made to formally fix syntaxa names as this is normally avoided in detailed local studies (Coetzee 1983).

\section{Results}

\section{Classification}

The following eight plant communities that can be grouped in five major community types were derived from the analysis (Table 1):

1. Buddleja glomerata-Rhus lucida Woodland

2. Themeda triandra-Merxmuellera disticha Grassland 


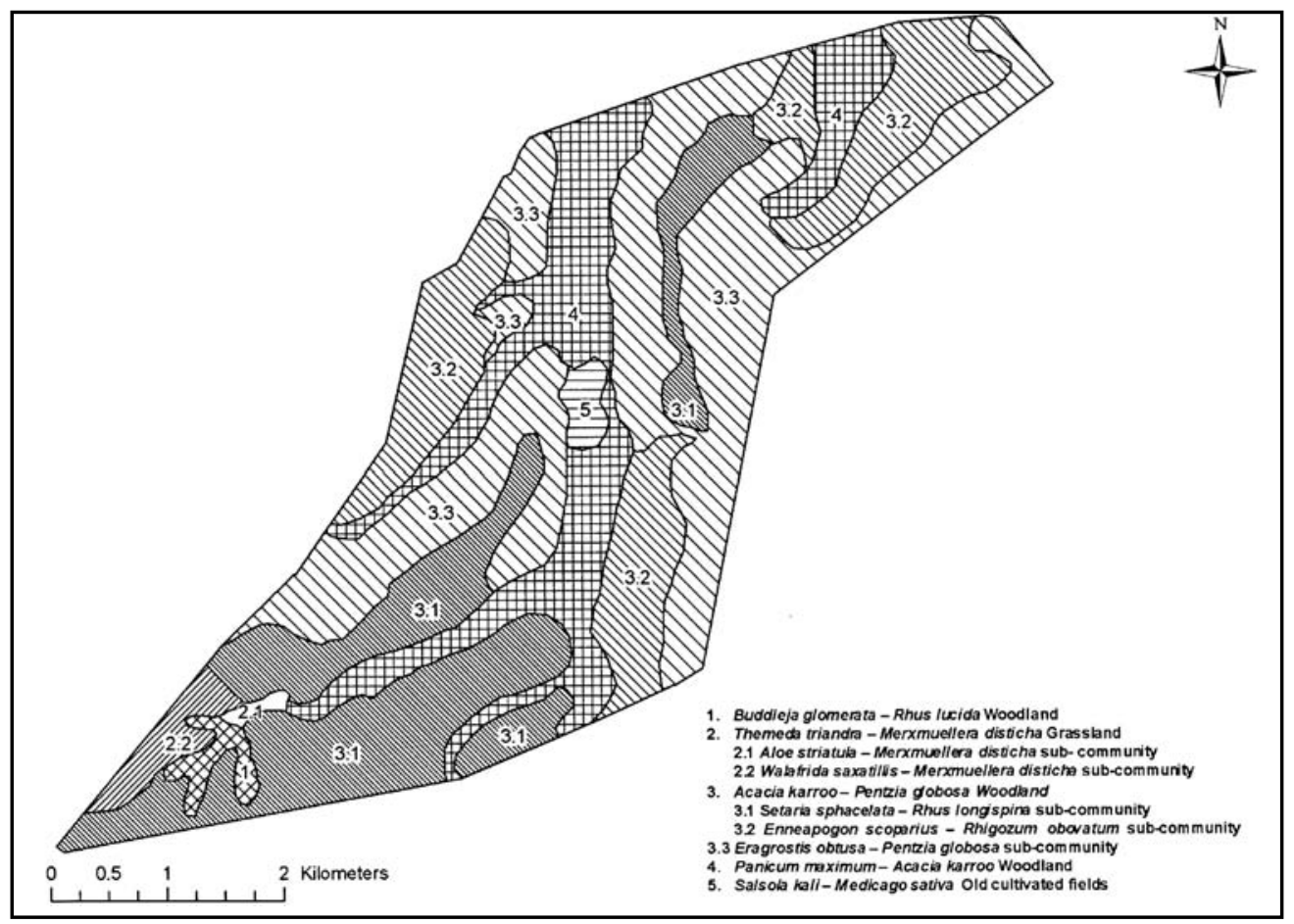

Fig. 2. The plant communities of the Ebenhaezer section of the Mountain Zebra National Park.

2.1 Aloe striatula-Merxmuellera disticha sub-community

\subsection{Walafrida saxatillis -}

Merxmuellera disticha sub-community

3. Acacia karroo-Pentzia globosa Woodland

3.1 Setaria sphacelata - Rhus longispina sub-community

3.2 Enneapogon scoparius Rhigozum obovatum sub-community

3.3 Eragrostis obtusa-Pentzia globosa sub-community

4. Panicum maximum-Acacia karroo Woodland

5. Salsola kali-Medicago sativa Old cultivated fields

\section{Description of the plant communities}

\section{Buddleja glomerata-Rhus lucida Woodland}

This plant community is found on the southern and south-east facing slopes in the western corner of the study area (Fig. 2). Characteristic of this community is steep slopes with scattered large rocks (sandstone). It can also be associated with the $\mathrm{Ib}$ land type and Mispah soil form. Rockiness was estimated at approximately $60 \%$.

The cover of the tree layer (Buddleja glomerata and Acacia karroo) was estimated at $30 \%$, the shrub layer at $60 \%$ (Rhus lucida and Tarchonanthus camphoratus) and the herbaceous layer at $10 \%$. Tree height varies between $4-5 \mathrm{~m}$ while the shrub height varies between 2-3 $\mathrm{m}$. 
This community is characterised by the presence of the tree Buddleja glomerata, the grass Melinis nerviglumis and the forbs Solanum supinum, Stachys cymbalaria, Stachys linearis, Moraea polystachya and Hibiscus pusillus (species group A, Table 1). The vegetation is dominated by the trees Buddleja glomerata (species group A) and Rhus lucida (species group G). The grasses Digitaria eriantha, Sporobolus fimbriatus (species group G) and Enneapogon scoparius (species group E) are prominent locally, while the shrubs Grewia occidentalis, Maytenus heterophylla (species group G) and the dwarf shrub Chrysocoma ciliata (species group G) are also present in this community (Table 1).

This community shows affinity with the Rhus lucida-Buddleja glomerata Shrubland described by Brown \& Bezuidenhout (2000) in the De Rust section of MZNP.

\section{Themeda triandra-Merxmuellera disticha Grassland}

The Themeda triandra-Merxmuellera disticha Grassland community is found in the south-western corner of the study area (Fig. 2). This community is situated on the plateau and midslopes (Ib and Da land types) with a gradient of approximately $8-25^{\circ}$. The habitat consists of moist shallow soil on a Mispah soil form and a rock cover of approximately $40-55 \%$.

Tree cover is estimated at $1 \%$, while the shrub stratum covers between $1-30 \%$ of the area (Fig. 2). The herbaceous cover is estimated at between $40-55 \%$. The average tree height varies between $1.5-3 \mathrm{~m}$, while the average height of the shrubs are $0.5 \mathrm{~m}$. The herbaceous layer is approximately $0.3 \mathrm{~m}$ tall.

This community is characterised by the presence of the grasses Merxmuellera disticha and Themeda triandra (species group B, Table 1) that also dominates the vegetation and can be divided into the following two sub communities:

\subsection{Aloe striatula-Merxmuellera disticha sub-community}

This sub-community is found on steep south facing slopes in the southern section of the study area (Fig. 2). The sub-community can be found on steep slopes ( $25^{\circ}$ gradient) in moist soil, which is covered with large rocks (sandstone) and has an estimated $50 \%$ rock cover. A Mispah soil form with underlying sandstone and shale is dominant in this community and situated on an Ib land type.

The cover of the tree layer is estimated at only $1 \%$ with an average height of $2.5 \mathrm{~m}$ while shrub layer with an average height of $1.5 \mathrm{~m}$ has an estimated $25-30 \%$ cover. The herbaceous layer is well represented and covers an area of approximately $55 \%$.

This community is characterised by the presence of species group C (Table 1) and includes the succulent Aloe striatula, the tree Cussonia paniculata, the shrubs Rhus erosa, Myrsine africana, Diospyros austroafricanum, Rhus dregeanum, Euclea crispa, Tarchonanthus camphoratus, Asparagus retrofractus, the grass Eragrostis curvula, the fern Cheilanthes hirta, and the forb Euryops nodosus. The vegetation is dominated by the grasses Themeda triandra, Merxmuellera disticha (species group B) and the succulent Aloe striatula (species group C, Table 1). Other prominent species associated with this vegetation type includes the tree Cussonia paniculata and the shrub Rhus erosa (species group C, Table 1).

Although this is the smallest community identified, less than one hectare in size, it contributes to the species richness of the area.

\subsection{Walafrida saxatillis-Merxmuellera disticha sub-community}

This vegetation is localised in the southern section of the study area, situated on the upper midslopes to the plateau area (Fig. 2). This sub-community is associated with the Da land type with shallow soil. Rock cover is estimated at $40-55 \%$ with medium size rocks present on an $8^{\circ}$ slope. 


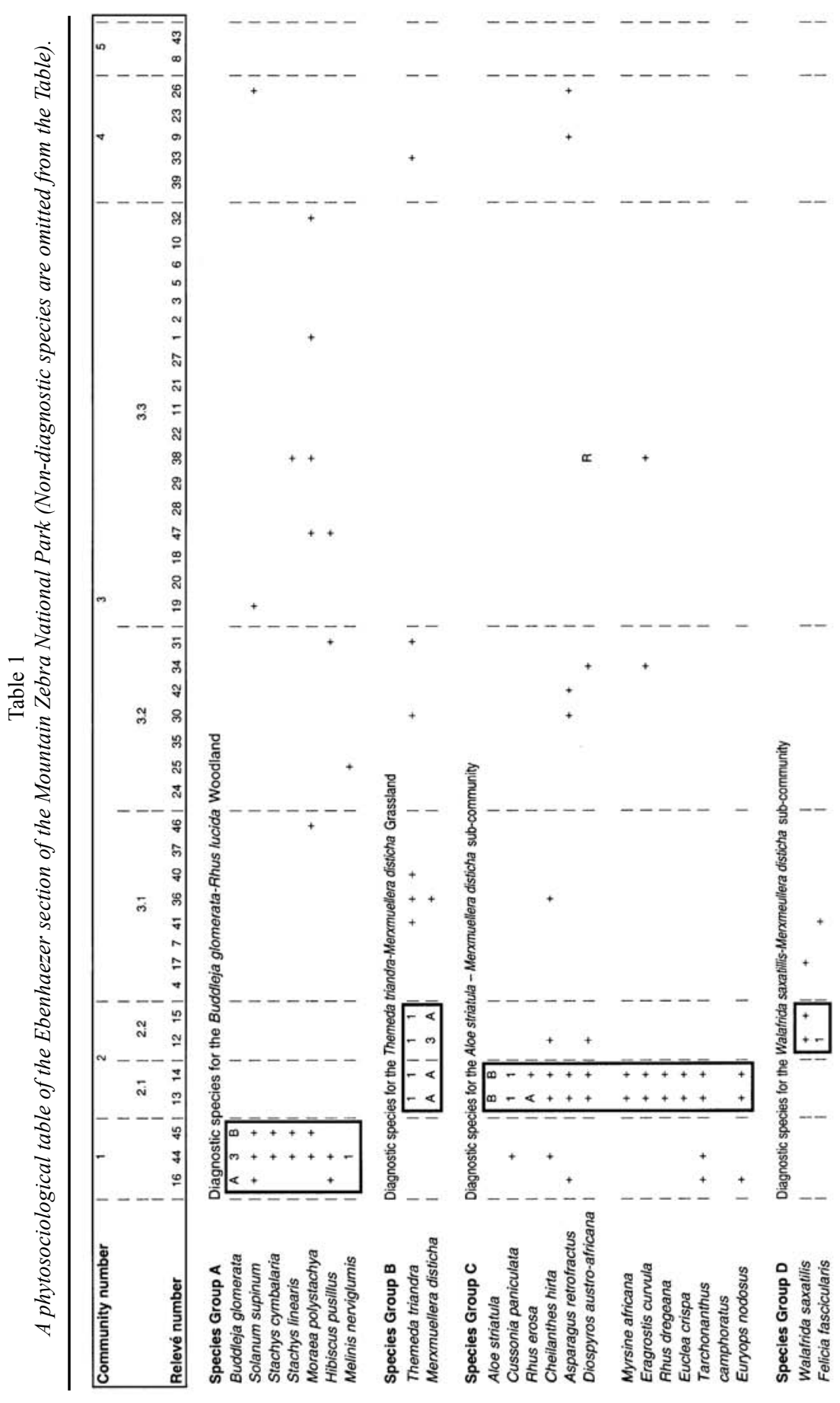




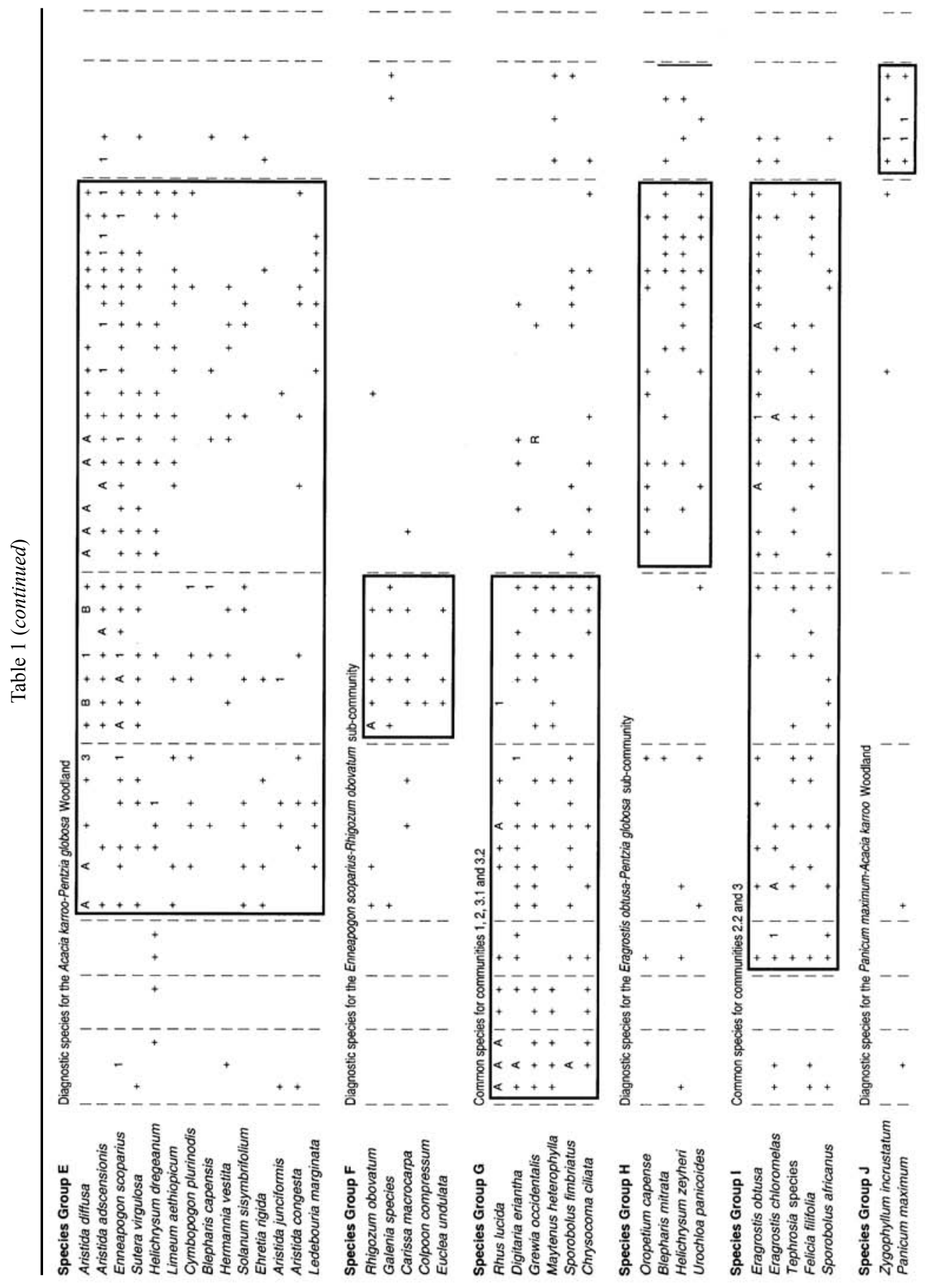




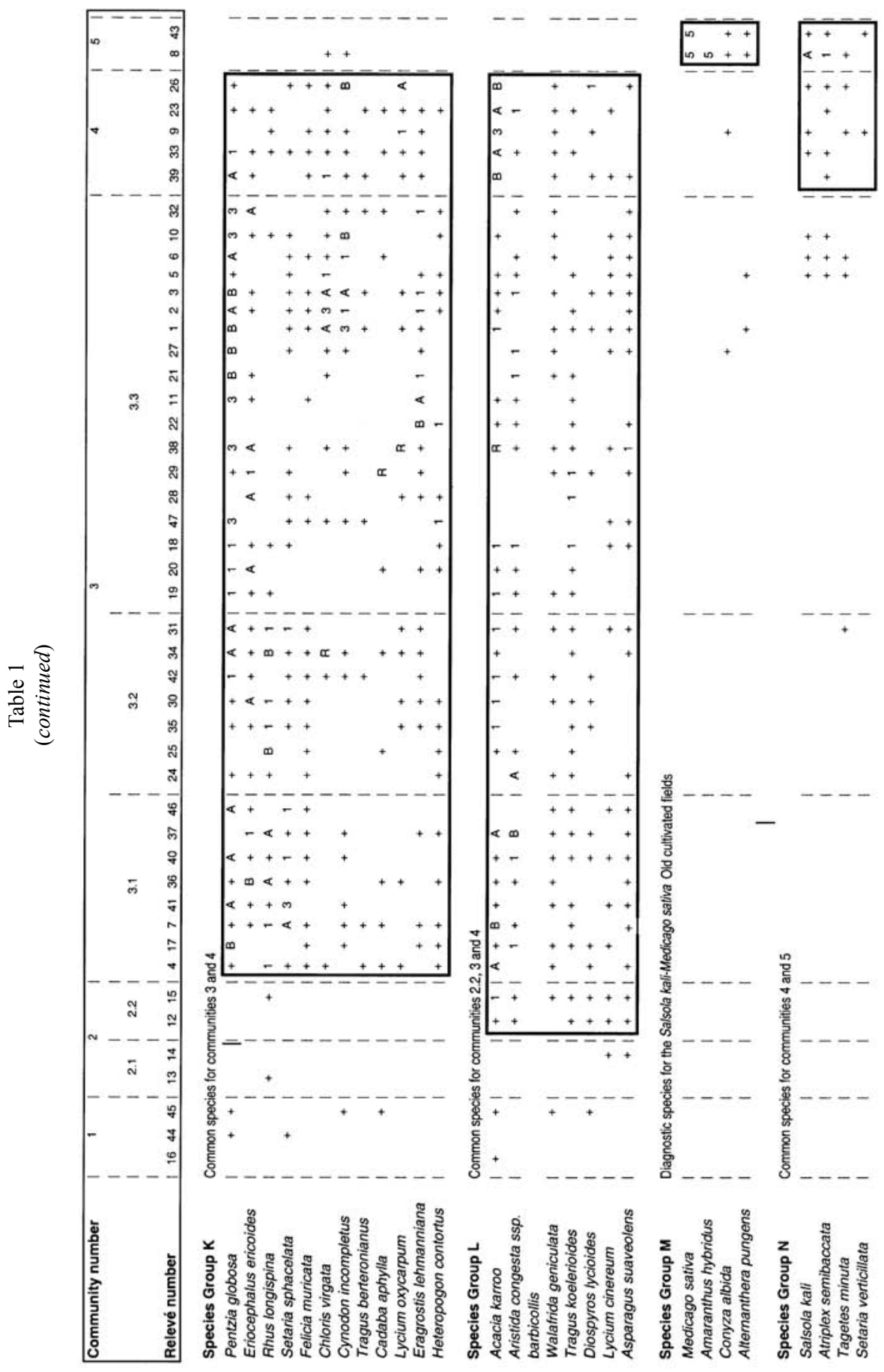


The cover of the tree layer is estimated at only $1 \%$ of the area, with an average height ranging between $2.5-3 \mathrm{~m}$, and is dominated by Acacia karroo. The shrub layer has an estimated $1 \%$ coverage with an average height of $1.5 \mathrm{~m}$, while the herbaceous layer with an average height of $0.6 \mathrm{~m}$ has an estimated $45-65 \%$ cover.

This community is characterised by the presence of the dwarf shrubs Walafrida saxatillis and Felicia fascicularis (species group D). The vegetation is dominated by the grasses Themeda triandra and Merxmuellera disticha that covers approximately $55 \%$ of the area. Other prominent species include the tree Acacia karroo (species group J) and the grass Eragrostis chloromelas (species group I, Table 1). The grass component showed indications that the grass sward may become moribund.

\section{Acacia karroo - Pentzia globosa Woodland}

The Acacia karroo-Pentzia globosa Woodland is found on all warm and dry footslopes and upper midslopes and includes the majority of plateau areas in this section (Fig. 2). This community is associated with the $\mathrm{Ib}$ and Fc land types, with Mispah (midslope) and Glenrosa (footslope) as the dominant soil types. Soil depth is limited by underlying limestone in the Glenrosa soil form. Rock cover varies between 15-60\% with underlying sandstone, shale and limestone.

The cover of the tree layer is estimated at $1-20 \%$, while the shrub stratum covers approximately $5-45 \%$ of the area. The cover of the herbaceous layer is estimated at $20-60 \%$. Tree height averages $2-3.5 \mathrm{~m}$, while shrubs are on average between $1.5-3.5 \mathrm{~m}$ in height. The herbaceous layer is approximately $0.3 \mathrm{~m}$ tall.

This community is characterised by the presence of the tree Ehretia rigida, the dwarf shrubs Helichrysum dregeanum, Limeum aethiopicum, the grasses Aristida diffusa, Aristida adscensionis, Aristida junciformis, Aristida congesta, Cymbopogon plurinodis,
Enneapogon scoparius and the forbs Sutera virgulosa, Blepharis capensis, Hermannia vestita, Solanum sisymbrifolium and Ledebouria marginata (species group E, Table 1). The vegetation is dominated by the dwarf shrub Pentzia globosa (species group K) and the grass Aristida diffusa (species group E). The dwarf shrub Eriocephalus ericoides (species group K) and the grasses Enneapogon scoparius and Aristida adscensionis (species group E) are co-dominant within this community (Table 1). Other species also prominent include the tree Acacia karroo (species group L), the shrub Rhus longispina (species group K), the grasses Setaria sphacelata, Heteropogon contortus (species group K), Aristida congesta subsp barbicollis (species group L) and the forb Walafrida geniculata (species group L, Table 1).

The abundance of the pioneer grass Aristida adscensionis (species group E) in large sections of this community indicates localised overgrazing that can be ascribed to previous farming activities in the area.

This community is divided into three subcommunities namely the Setaria sphacelata -Rhus longispina sub-community, the Enneapogon scoparius-Rhigozum obovatum sub-community and the Eragrostis obtusaPentzia globosa sub-community:

\subsection{Setaria sphacelata-Rhus longispina sub-community}

This woodland is found on warm, dry footslopes to midslopes and plateaux (Fig. 2). This community is associated with the $\mathrm{Ib}$ land type. The surface is covered with small to medium sized rocks covering an estimated $15-60 \%$ of the area. The dominant soil-rock complex is a Mispah soil with underlying sandstone and shale.

Tree cover is estimated at $15 \%$ with an average height of $2.5-3 \mathrm{~m}$, while the shrub layer covers between $5-10 \%$ of the area and is approximately $1.5-3.5 \mathrm{~m}$ in height. The cover of the herbaceous layer is estimated at $60 \%$ of the area with an average height of $0.3 \mathrm{~m}$. 
This community is characterised by the absence of a diagnostic species group and is dominated by the dwarf shrub Pentzia globosa (species group K) and the tree Acacia karroo (species group L) while the shrub Rhus longispina and the grass Setaria sphacelata (species group K) are co-dominant (Table 1). Prominent species are the dwarf shrub Eriocephalus ericoides (species group K) and the grasses Aristida congesta subsp barbicollis (species group L), Heteropogon contortus (species group K) and Digitaria eriantha (species group G, Table 1).

\subsection{Enneapogon scoparius-Rhigozum obovatum sub-community}

This vegetation type can be found on lower and upper midslopes throughout the section (Fig. 2). The Fc land type is associated with this community. Underlying limestone is characteristic of this land type on the footslope and valley bottom areas (Land Type Survey Staff 1999). The geology consists of mudstone and sandstone while the soil is classified as the Glenrosa soil form. Soil depth is limited by the under lying limestone and averages $150 \mathrm{~mm}$. Small to medium sized rocks are scattered over the area with an average cover of $20-40 \%$.

The tree layer covers $1-5 \%$ of the area with an average height of $2-3 \mathrm{~m}$, while shrub cover is estimated at 5-20\% and varies in height between $1.5-3 \mathrm{~m}$. The herbaceous layer covers an estimated $45 \%$ of the area with an average height of $0.3 \mathrm{~m}$.

This community is characterised by species from species group $\mathrm{F}$ (Table 1) and include the shrubs Rhigozum obovatum, Carissa macrocarpa, Colpoon compressum, Euclea crispa and the forb Gallenia spp. The vegetation is dominated by the shrubs Rhus longispina (species group K), Rhigozum obovatum (species group F) and the grasses Aristida diffusa and Enneapogon scoparius (species group E, Table 1). Other species also prominent include the tree Acacia karroo and the dwarf shrubs Pentzia globosa, Eriocephalus ericoides and Felicia filifolia (species group $\mathrm{K}$, Table 1).
Though not listed in Table 1, the grass Cenchrus ciliaris was found to be locally dominant within this sub-community at higher points below cliffs. This community was previously heavily grazed and some places are severely disturbed with signs of sheet and donga erosion present.

The Enneapogon scoparius-Rhigozum obovatum sub-community shows affinity with the Enneapogon scoparius-Ehretia rigida sub-community of the De Rust area, described by Brown \& Bezuidenhout (2000).

\subsection{Eragrostis obtusa-Pentzia globosa sub-community}

This sub-community can be found on plateaux and midslopes throughout the study area (Fig. 2). This community is associated with the $\mathrm{Ib}$ land type and comprises approximately $32 \%$ of the study area. This habitat consists of shallow soil on a Mispah soil form and a rock cover that varies between $5-55 \%$. The habitat is also found on plateaux and upper midslopes facing east and west, as well as footslopes leading into drainage lines.

Trees and shrubs comprise only $1-2 \%$ of the vegetation and are seldom taller than $2.5 \mathrm{~m}$. The cover of the herbaceous layer varies between $20-45 \%$ with an average height of $0.3 \mathrm{~m}$.

The presence of the dwarf shrub Helichrysum dregeanum, the grasses Oropetium capense, Urochloa panicoides and the forb Blepharis mitrata is characteristic for this large sub-community (species group $\mathrm{H}$, Table 1). The vegetation is dominated by the dwarf shrubs Pentzia globosa and Eriocephalus ericoides (species group K) together with the grass Eragrostis obtusa (species group I, Table 1). Other species also prominent include the dwarf shrub Walafrida geniculata (species group K) and the grasses Aristida diffusa, Aristida adscensionis, Enneapogon scoparius (species group E), Heteropogon contortus, Eragrostis lehmanniana (species group K) and Tragus koelerioides (species group L, Table 1). 
Locally some patches are dominated by the grasses Cynodon incompletus and Chloris virgata (species group L, Table 1). These patches have been heavily grazed in the past by goats and sheep, leading to the presence of these pioneer grasses. Bush encroachment by the tree Acacia karroo (species group L, Table 1) was also noted in some areas within this sub-community.

\section{Panicum maximum-Acacia karroo Woodland}

This community consists of the drainage lines and the Wilgerboom River, and comprises approximately $30 \%$ of the study area (Fig. 2). The Wilgerboom River is perennial while the drainage lines only flow after heavy thunderstorms. This area has been seriously mismanaged and some areas are disturbed with erosion patches visible. The habitat is situated on the Fc land type with Hutton, Oakleaf and Swartland soil forms present. Rock cover is less than $5 \%$ and consists mainly of small rocks.

Tree height varies between $3.5-5 \mathrm{~m}$ while tree cover varies between $20 \%$ in the upper catchment areas to $60 \%$ in the drainage lines and river. The average shrub height is approximately $2.5 \mathrm{~m}$ and covers $15 \%$ of the area. The herbaceous layer covers an estimated $35 \%$ of the area with an average height of $0.25 \mathrm{~m}$.

This Woodland is characterised by the presence of the dwarf shrub Zygophyllum incrustatum and the grass Panicum maximum (species group $\mathrm{J}$, Table 1 ). The vegetation is dominated by the tree Acacia karroo (species group L) and the grass Panicum maximum (species group J, Table 1). Other prominent species include the tree Lycium oxycarpum (Species Group K), the dwarf shrubs Zygophyllum incrustatum (species group J), Pentzia globosa and the grasses Chloris virgata and Cynodon incompletus (species group K, Table 1). Pioneers species like Atriplex semibaccata and Salsola kali (Species group N) are prominent on disturbed soil.
This community has affinity with the Becium burchellianum-Acacia karroo Woodland and Sporobolus africanus-Acacia karroo Woodland described by Brown \& Bezuidenhout (2000).

\section{Salsola kali-Medicago sativa Old cultivated fields}

This small community ( $<1 \%$ of total area) consists of old cultivated fields situated in the drainage line of the study area (Fig. 2). Rock cover is $0 \%$ and slope $0-1 \%$.

The vegetation consists only of a herbaceous component with the grasses and forbs covering an estimated $80 \%$ of the area with an average height of $0.4 \mathrm{~m}$.

This community is characterised by the presence of the forbs Medicago sativa (lucerne) Amaranthus hybridus, Conyza albida and Alternanthera pungens (Species Group M, Table 1). This old field community is dominated by lucerne Medicago sativa (species group M), while the forbs Salsola kali and Atriplex semibaccata are also prominent locally. Due to the disturbed nature of this community it does not contribute to the conservation or biological value of this study area.

\section{Discussion and conclusion}

From the eight communities identified in the study area, three communities have affinities with four communities described by Brown \& Bezuidenhout (2000) for the De Rust section of Mountain Zebra National Park. A further two communities indicate affinity with two communities described by Van Der Walt (1980) in the old proclaimed section of MZNP. This study proves that the extended land incorporated into the park contributes to the biological diversity of the park by adding more vegetation communities and habitat types to the area. The expansion of MZNP does not only contribute floristically to the diversity of the park but also faunally due to the inclusion of new habitats into the park which make it suitable for the introduction of 
larger herbivores that occurred in this region before.

Data obtained from this study will be incorporated into the draft management plan for the larger MZNP. This will be in line with the mission and vision statement of South African National Parks, for example, to conserve the faunal and floral assemblages and ecological processes that characterise the northeastern karoo areas, and to actively preserve this for the appreciation by visitors.

\section{Acknowledgements}

The following individuals and institutions are sincerely thanked: National Research Foundation (NRF) and Technikon SA for financing this study; South African National Parks, especially Park Management of Mountain Zebra, for allowing and encouraging the research; Dr Stephen Holness for the assistance with the maps and $\mathrm{Mr}$ Ernest Daemane (Kimberley South African National Parks Herbarium - KSAN) for verifying the plant species names.

\section{References}

Acocks, J.P.H. 1988. Veld types of South Africa. 3rd ed. Memoirs of the botanical Survey of South Africa 57: 1-146.

ARNold, T.H. \& B.C. DE WET. 1993. Plants of Southern Africa: Names and distribution. Memoirs of the botanical Survey of South Africa. 62: 1-825.

Bezuidenhout, H. 1993. Syntaxonomy and synecology of Western Transvaal Grasslands. Ph.D dissertation. University of Pretoria, Pretoria.

Bezuidenhout, H., H.C. Biggs \& G.J. BRedenKamp. 1996. A process supported by the utility BBPC for analysing Braun-Blanquet data on a personal computer. Koedoe 39: 107-112.

Brown, L.R. 1997. A plant ecological and wildlife management plan of the Borakalalo Nature Reserve, North-west Province. Ph.D. dissertation. University of Pretoria, Pretoria.

Brown, L.R. \& H. Bezuidenhout. 2000. The phytosociology of the De Rust section of the Mountain Zebra National Park, Eastern Cape. Koedoe 43(1): 1-18

Coetzee, B.J. 1983. Phytosociology, vegetation structure and landscapes of the Central District, Kruger National Park. Dissertationes Botanicae 69: $1-456$.
ECKHARDT, H.C. 1993. A synecological study of the vegetation of the north-eastern Orange Free State. M.Sc. thesis. University of Pretoria, Pretoria.

EDWARDS, D. 1972. Botanical survey and agriculture. Proceedings of the Grassland Society of southern Africa 7: 15-19.

EDWARDS, D. 1983. A broad-scale structural classification of vegetation for practical purposes. Bothalia 14: 705-712.

GöTZE, A.R. 2002. The classification of plant communities and the evaluation of restoration technologies in different land-use areas in the Vhembe-Dongola National Park, Northern Province, South Africa. M. Sc. thesis. Potchefstroom University for Christian Higher Education, Potchefstroom.

Harper, J.L. \& D.L. Hawksworth. 1995. Preface. P.10. In: Hawksworth, D.L. (ed) Biodiversity, Measurement and Estimation. Chapman \& Hall. London.

HiLl, M.O. 1979. TwINSPAN: A Fortran Program For Arranging multivariate data in an ordered twoway table by classification of individuals and attributes. New York: Cornell University.

Hoffman, T. 1996. Eastern Mixed Nama-Karoo. P.55. In: Low, A.B. \& A.G. Rebelo (eds.). Vegetation of South Africa, Lesotho and Swaziland. Pretoria: Departement of Environmental Affairs \& Tourism.

Land TyPe Survey Staff. 1986. Land types of the map SE27/20 Witdraai, 2720 Noenieput, 2722 Kuruman, 2724 Christiana, 2820 Upington, 2822 Postmasburg. Menoirs of the Agricutural Natural Resources of Southern Africa 3: 1-185.

Land Type Survey StafF. 1999. Land types occurrence (maps) and areas of 3224 Graaff-Reinet. Unpublished information obtained from Institute for Soil, Climate and Water, Pretoria.

Mueller-Dombois, D. \& H. EllenBerg. 1974. Aims and methods of vegetation ecology. New York; Wiley.

Pond, U., B.B. Beesley, L.R. Brown \& H. BEZuidenhout. 2002. Floristic analysis of the Mountain Zebra National Park, Eastern Cape. Koedoe 45 (1): 35-37.

Soll Classification Working Group. 1991. Soil classification: a taxonomic system for South Africa. Memoirs on the Agriculrural Natural Resources of South Africa 15: 1-262.

VAN DER WALT, P.T. 1980. A phytosociological reconnaissance of the Mountain Zebra National Park. Koedoe 23:1-32.

WAHL, M. \& K. NAUDE. 1996. National register of protected areas in South Africa. Pretoria: Department of Environmental Affairs and Tourism. 